\title{
Germanica
}

GERMANICA $7 \mid 1990$

Grenze und Entgrenzung

\section{Nilpferde zum Beispiel, oder Vögel}

\section{Margrit Baur}

\section{OpenEdition}

Journals

Édition électronique

URL : http://journals.openedition.org/germanica/2507

DOI : 10.4000/germanica.2507

ISSN : 2107-0784

\section{Éditeur}

Université de Lille

\section{Édition imprimée}

Date de publication : 30 juin 1990

Pagination : 143-146

ISSN : 0984-2632

\section{Référence électronique}

Margrit Baur, « Nilpferde zum Beispiel, oder Vögel », Germanica [Online], 7| 1990, Online erschienen am 20 Mai 2014, abgerufen am 06 Oktober 2020. URL : http://journals.openedition.org/germanica/2507 ; DOI : https://doi.org/10.4000/germanica.2507

Ce document a été généré automatiquement le 6 octobre 2020.

(c) Tous droits réservés 


\title{
Nilpferde zum Beispiel, oder Vögel
}

\author{
Margrit Baur
}

Die Alte Frau: (kichert) Du träumst.

Der Alte Mann: Nass, ja. Die Träume haben nasse Füsse. Sie werden ersaufen zuletzt.

Die Alte Frau: Oder schwimmen.

Der Alte Mann: Fische? Wo nähme man die Angel her.

Die Alte Frau: Delphine kann man zähmen. Oder fast. Goldfische hingegen.

Der Alte Mann: Die sind fad. Das bisschen Farbe ist bloss Verkleidung. Und China liegt weit zurück.

Die Alte Frau: China?

Der Alte Mann: Ihr Ausgangspunkt.

Die Alte Frau: Aber Forellen sind schön.

Der Alte Mann: Bei Schubert. Und tückisch, (irritiert) Oder sagt er nicht so?

Die Alte Frau: (abwesend) Auch Seerosen schwimmen.

Der Alte Mann: Kitsch.

Die Alte Frau: Nilpferde?

Der Alte Mann: Wieso.

Die Alte Frau: Die dicke Haut.

Der Alte Mann: Eben. Gehört nicht hierher.

Die Alte Frau: Und der Regen?

Der Alte Mann: Du lenkst ab.

Die Alte Frau: Die Träume.

Der Alte Mann: Gehen dich nichts an.

Die Alte Frau: (friedlich) Ich träume auch.

Der Alte Mann: Trocken.

Die Alte Frau: Sozusagen. 
Der Alte Mann: (hämisch) Wüstenträume.

Die Alte Frau: Mit Flügeln.

Der Alte Mann: Du lügst.

Die Alte Frau: Vielleicht.

Der Alte Mann: In deinem Alter.

Die Alte Frau: Junge lügen schlecht. Du hast immer schlecht gelogen.

Der Alte Mann: Eine Unterstellung.

Die Alte Frau: Eine schwarze Wahrheit. Siehst du? Lügen sind bunt.

Der Alte Mann: Hagelwolkengelb.

Die Alte Frau: (begeistert) Wegwartenblau, eidechsengrün, blutund kaminfeuerrot.

Der Alte Mann: Geschmacklos.

Die Alte Frau: Lang nicht genug.

Der Alte Mann: Früher hast du Geschmack gehabt.

Die Alte Frau: Wirklich?

Der Alte Mann: Nie hättest du das Nilpferd erwähnt. Du hättest dich geschämt wie für einen hässlichen Hut.

Die Alte Frau: Ich habe nie einen Hut gehabt.

Der Alte Mann: Nur als Beispiel.

Die Alte Frau: Es passt nicht. Beispiele müssen passen.

Der Alte Mann: Ach. Und Hüte nicht?

Die Alte Frau: Wir sind beim Nilpferd.

Der Alte Mann: Gewesen. Nehmen wir dein Gesicht.

Die Alte Frau: Beim Wort?

Der Alte Mann: Wie es war.

Die Alte Frau: Das kannst du nicht nehmen.

Der Alte Mann: Es war glatt.

Die Alte Frau: Alles ist einmal nichts gewesen, bevor es etwas geworden ist.

Der Alte Mann: Zitat.

Die Alte Frau: Wahrscheinlich.

Der Alte Mann: Ohne Quellenangabe, schamlos. Mich beschummeist du nicht.

Die Alte Frau: (leise) Pfadfinder!

Der Alte Mann: Sei still.

Die Alte Frau: Allzeit bereit für die nackte Wahrheit.

Der Alte Mann: Du redest zuviel.

Die Alte Frau: Stimmt. Und du denkst. An ein glattes Gesicht?

Der Alte Mann: Du warst schön.

Die Alte Frau: Und weiter?

Der Alte Mann: Jeder hat es gesagt.

Die Alte Frau: (wegwerfend) Schnee vom vergangenen Jahr. Dafür bist du nicht zuständig. Du behältst nur den Regen. 
Der Alte Mann: Während du natürlich -

Die Alte Frau: Ich behalte gar nichts.

Der Alte Mann: Verschwendung.

Die Alte Frau: Mag sein.

Der Alte Mann: (beinahe mitleidig) Du bist steif vor Kalk.

Die Alte Frau: Aber nicht blind.

Der Alte Mann: Ach. Und was siehst du?

Die Alte Frau: Schäfchenwolken. Bäume. Kiesel, Einen alten Mann.

Der Alte Mann: So alt auch nicht.

Die Alte Frau: Alt wie die Welt.

Der Alte Mann: (boshaft) Etwa wie du.

Die Alte Frau: Prosaisch. Du setzt dich herab.

Der Alte Mann: Und wer hat gewusst, dass die Goldfische aus China sind?

Die Alte Frau: Ich nicht.

Der Alte Mann: Da siehst du.

Die Alte Frau: Ziemlich unscharf. Sehen sie chinesisch aus?

Der Alte Mann: Unter der Verkleidung bestimmt.

Die Alte Frau: (rasch) Die lass ihnen. Sie ist hübsch.

Der Alte Mann: Und glitschig.

Die Alte Frau: Für die Augen nicht.

Der Alte Mann: Sie trügen. Das Wissen zählt.

Die Alte Frau: Wo der Schuh drückt. Was dahinter steckt. Woher der Wind weht.

Der Alte Mann: (witternd) Woher?

Die Alte Frau: Von vorn.

Der Alte Mann: Es wird regnen.

Die Alte Frau: Wir werden in der Sonne gesessen haben.

Der Alte Mann: Trost der Grammatik. Ich mag keine Tricks.

Die Alte Frau: Die dicke Haut.

Der Alte Mann: Du wiederholst dich.

Die Alte Frau: Die Vögel wiederholen sich auch.

Der Alte Mann: (wütend) Zum Beispiel. Aber Beispiele müssen passen.

Die Alte Frau: Soll ich singen?

Der Alte Mann: Verschon mich. Sag lieber, was du siehst.

Die Alte Frau: Keinen Regen, (kichert) Du bist schlecht rasiert.

Der Alte Mann: Ach. Was schliesst du daraus?

Die Alte Frau: Nichts. Du siehst besser aus, wenn du sauber rasiert bist.

Der Alte Mann: Lass mein Gesicht.

Die Alte Frau: Und kein Wort von den Träumen?

Der Alte Mann: Ich träume nicht. 